\title{
HAKIKAT KEHARAMAN RIBA DALAM ISLAM
}

\author{
Khozainul Ulum \\ Program Studi Ekonomi Syariah \\ Fakultas A gama Islam U niversitas Islam Lamongan \\ e-mail: averroz@gmail.com
}

\begin{abstract}
There is a negative assumption that arises in community with regard to economic transactions. For example, the statement "interest" and "profitsharing" is similar, it justifies something that has become a previous habit. Whereas after having studied and researched, the economic transactions is belongings to the category of riba (usury) and society is still reluctant to get used to something right, which has not yet become a tradition. So, it is impressed that Islam does not take care of worship that do not directly relate to Allah, as obligatory (mahdoh) worship in the pillars of Islam. The question arising then is why the statement emerged from the realm of M uslims who are still reluctant to attempt to transact transactions that should be appraised with shariah paradigm? How is the danger of riba, in the world and the Hereafter?

A uthor wants to convey thoughtfulness and perception related to economic thought developing at this time. They merely legitimize the phenomenon of conventional economics by attaching ayat and hadits although there are also alternative thoughts of genuine Islamic Economics, so easy to get caught up in usurious practice. Therefore, author is inspired to invite readers to dare to unburden, examine, and study riba (usury) and the reason of prohibition in Islam. The existence of incompatibility of Islamic economic theory with the application of contemporary economics does not mean that Islamic economics is not applicable, but it motivates us to implant Islamic economics proportionally and objectively in life. In order to analyze the problems, in this article, author uses a combination of mindset based on reality with faith, then author draws conclusion on the nature of reality of transaction, by comparing reality with argument and opinion relating to" Does interest applied nowadays include riba and how is the danger of consuming usurious results?"
\end{abstract}

Keyword Riba, interest, the danger of riba

\section{Pendahuluan}

A da anggapan-anggapan negatif yang muncul di tengah masyarakat berkaitan dengan transaksi yang dianggap ribawi dan terkait masalah bunga bank atau bunga dari pinjaman uang di koperasi atau lembaga keuangan lainnya yang masih mengesampingkan soal ribawi atau tidak yang penting memudahkan transaksi dan tidak ribet. M unculnya opini itu tidak luput dari pernyataan dan sikap dari kaum muslimin sendiri, yang masih belum tahu dan tidak mau tahu tentang detail mekanisme bunga maupun transaksi yang ribawi dan image masyarakat tentang riba biasanya selalu tertuju pada bunga bank dan aktivitas pembungaan uang semisal rente. 
A danya kesalahan pandangan bahwa hukum itu harus mengikuti realita, bukan realita yang harus disesuaikan dengan hukum/syara'. Juga adanya pandangan pragmatis buah dari kapitalisme bahwa kita tidak bisa hidup tanpa bunga, sehingga meskipun bunga dianggap atau benar-benar ekuevalen/sebangun dengan riba tetap diterjang dan tetap dijalankan dalam aktivitas/transaksi ekonomi dan bisnis sehari-hari.

B eberapa pemikiran ekonomi yang berkembang saat ini, bisa jadi sekedar melegitimasi fenomena ekonomi konvensional dengan memaksakan tambahan dalil dari ayat atau hadits, meskipun ada juga pemikiran-pemikiran alternatif yang genuin ekonomi Islam. Adanya ketidaksesuaian teori ekonomi Islam dengan aplikasi ekonomi kontemporer bukan berarti ekonomi Islam tidak aplicable, namun justru memotivasi kita bagaimana membumikan ekonomi Islam secara proporsional dan obyektif dalam kehidupan.

\section{Kajian tentang Riba}

1. Pengharaman riba

Riba terdiri dari huruf ra dan ba, dan huruf mu'tal akhir, hanya memiliki satu makna yaitu: al-ziyadah (tambahan), al-nama' (tumbuh dan berkembang). ${ }^{1}$ T erjemahan harfiah dari kata riba dalam bahasa Arab adalah peningkatan, penambahan atau pertumbuhan, meskipun secara popular diterjemahkan sebagai bunga. ${ }^{2}$

Dalam al-Quran, ayat pertama kali (tahap pertama) yang berbicara riba adalah :

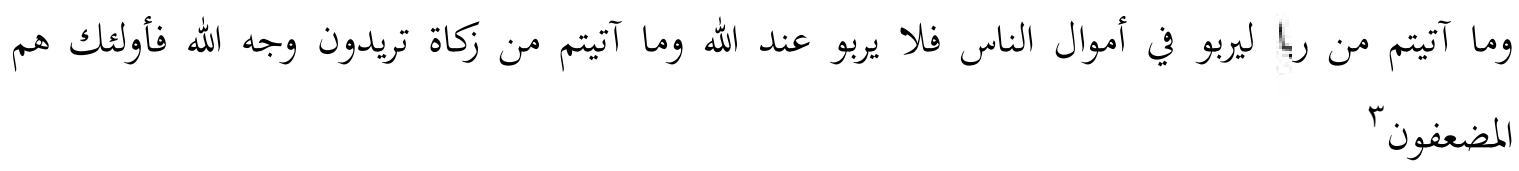

Di sini belum dijelaskan bahwa riba itu adalah haram, namun Allah memberikan alternatif pembelanjaan keuangan yang akan memberikan return lebih baik dan lebih banyak. Para mufassir berbeda pendapat mengenai riba yang dibicarakan dalam ayat di atas. A da yang berpendapat bahwa riba dalam ayat ini bukan riba yang diharamkan. Riba dalam ayat ini berupa pemberian sesuatu kepada orang lain yang tidak didasarkan keikhlasan seperti pemberian hadiah dengan harapan balasan hadiah yang lebih besar. ${ }^{4}$ Sedangkan al-A lusi dan Sayyid Qutb berpendapat bahwa riba dalam ayat tersebut adalah tambahan yang dikenal dalam muamalah sebagai yang diharamkan oleh Syari' ${ }^{5}$

T ahap kedua dari penetapan status hukum riba adalah dengan turunnya ayat :

\footnotetext{
${ }^{1}$ A bi husain A hmad ibn Faris ibn Zakariah, M aqayis al-L ughah (Beirut: Dar Ihya' al-Turats al-A rabiy, 2001), 419

2 Tarek el Diwany, Bunga Bank dan Masalahnya; Suatu Tinjauan Syar'i dan Ekonomi Keuangan (Jakarta: A K BA R M edia Eka Sarana, 2003), 171

${ }^{3}$ Q.S. ar Rum: 39

${ }^{4}$ Ibn 'A rabi, A hkam al-Quran, Ed. M. Ali al-Bajawi, juz 3 (Q ahirah: Dar Ihya' al-Kutub al-'A rabiyah, 1957), 1479. Lihat juga Ibn Kasir, Tafsir al-Quran al-'A zim, juz 3 (Q ahirah: Dar Ihya' al-Kutub al-'A rabiyah, 1952), 434

${ }^{5}$ Sayyid Qutb, Fi Zilal al-Quran, juz XXI (B eirut: Dar al-Turas al-'A rabi, 1967), 460
} 


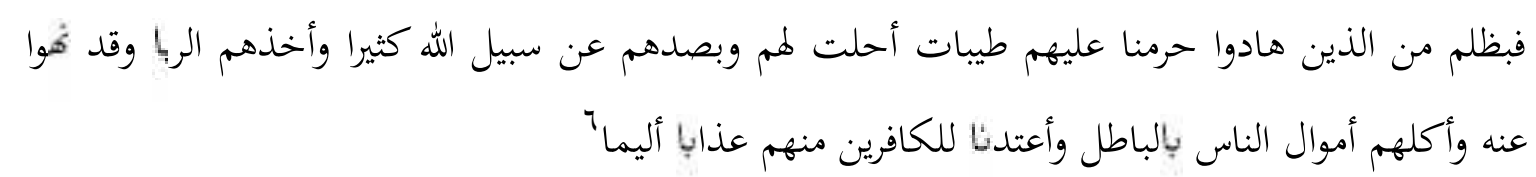

Ayat di atas menjelaskan bahwa riba merupakan amalan yang sejak dahulu dilakukan oleh orang-orang $Y$ ahudi, padahal A llah telah melarangnya.

Tahap ketiga, adalah pelarangan umat Islam untuk memungut riba yang berlipat ganda sebagaimana terdapat dalam ayat :

$$
\text { يا أيها الذين آمنوا لا تأكلوا الربا أضعافا مضاعفة واتقوا الله لعلكم تفلحون : }
$$

Di dalam ayat tersebut secara tegas dilarang pemungutan riba secara berlipat ganda. Secara umum, ayat ini harus dipahami bahwa kriteria berlipat ganda bukanlah merupakan syarat dari terjadinya riba (jika bunga berlipat ganda maka riba, tetapi apabila kecil bukan riba). Ini merupakan sifat umum dari praktik pembungaan uang pada saat itu. ${ }^{8}$ Demikian juga ayat ini harus dipahami secara komprehensif dengan ayat 278279 dari surah al-B aqarah yang turun pada tahun ke-9 Hijriyah.

Tahap keempat (terakhir) adalah dengan turunnya ayat al-Quran :

$$
\begin{aligned}
& \text { يا أيها الذين آمنوا اتقوا الله وذروا ما بقي من الربا إن كنتم مؤمنين فإن لم تفعلوا فأذنوا بحرب من الله ورسوله } \\
& \text { وإن تبتم فلكم رءوس أموالكم لا تظلمون ولا تظلمون } 9
\end{aligned}
$$

A yat di atas merupakan kelompok ayat terakhir yang berbicara tentang riba. A yat tersebut merupakan ketegasan atas praktek riba yang dilakukan oleh penduduk Makkah dengan penduduk Tha'if.

A yat-ayat di atas secara bertahap memberikan status hukum yang jelas tentang riba. A yat-ayat yang terakhir turun yang membahas tentang riba telah menegaskan bahwa riba adalah haram, karenanya harus ditinggalkan dan menggantinya dengan zakat, sedekah, dan infaq serta transaksi lain yang bernilai kebaikan di hadapan A llah.

2. Riba dalam pandangan ulama tafsir.

Tidak semua mufassir mengemukakan definisi riba dalam penafsiran mereka. Banyak di antara mereka yang dalam menjelaskan pengertian riba hanya dengan menerangkan bahwa perilaku tertentu termasuk riba, tanpa menyebut definisi. AlThabari misalnya, yang dikenal sebagai tokoh tafsir bi al-ma'sur hanya memberi sedikit ulasan kemudian mengemukakan banyak hadits. Ia mengatakan bahwa yang dimaksud dengan wa in tubtum falakum ruusu amwabikum adalah jika kamu taubat kemudian meninggalkan makan riba dan kembali kepada (hukum) Allah, maka hakmu hanyalah jumlah pinjaman yang hendak dibayarkan peminjam kepadamu tanpa ada tambahan, seperti yang pernah kamu lakukan sebagai riba. ${ }^{10}$

\footnotetext{
${ }^{6}$ Q.S. an-Nisa: $160-161$

${ }^{7}$ Q.S. Ali 'Imran: 130

${ }^{8}$ M uhammad Syafi'i A ntonio, Bank Syari'ah; Dari Teori ke Praktik (J akarta: Gema Insani Press, 2001), 49

${ }^{9}$ Q.S. al-B aqarah: $278-279$

${ }^{10}$ M uh. Zuhri, Riba dalam A I-Quran dan Masalah Perbankan; Sebuah Tilikan Antisipatif (Jakarta: PT. Raja Grafindo Persada, 1997), 90
} 
Al-K hazin juga tidak mendefinisikan riba. Ia mengatakan bahwa orang yang berhutang dan menjanjikan akan memberikan tambahan ketika pelunasan hutang berarti telah melakukan riba. Selanjutnya al-K hazin menyinggung beberapa hadits. ${ }^{11}$

Demikian juga Fakhr al-Razi juga tidak mendefinisikan riba dalam penafsirannya. A walnya beliau menyebut pengertian menurut bahasa, yaitu sebagai istilah untuk arti tambahan. Kemudian beliau membagi riba mebjadi dua, yaitu riba fadl dan riba nasi'ah, seperti juga ulama lain. Kemudian al-Razi memberi gambaran tentang riba nasi'ah yang juga riba J ahiliyyah dalam bentuk kasus. M enurut al-Razi, riba nasi'ah adalah riba yang dikenal di masa Jahiliyyah, yaitu mereka menyerahkan sejumlah harta kepada orang lain dengan menarik jumlah tambahan tertentu setiap bulan, sementara jumlah pinjaman masih utuh. Kemudian bila tiba jatuh temponya, mereka menagih. Bila peminjam berhalangan mengembalikan pinjaman, mereka menambah "hak" dan tenggang waktu. Inilah riba yang mereka praktekkan di masa J ahiliyyah. ${ }^{12}$

Tidak begitu jelas mengapa para mufassir dalam menafsirkan ayat-ayat riba tidak merumuskan definisinya. Bisa jadi mereka mempunyai jalan pikiran seperti Ibnu Taimiyyah. Bagi Ibnu Taimiyyah, definisi bukan faktor penting untuk menangkap hakikat sesuatu. Pengetahuan tentang sesuatu dapat diperoleh melalui pengalaman empirik tanpa didefinisikan terlebih dahulu. ${ }^{13}$ Sepertinya, mufassir mutaakhirlah yang dalam menafsirkan ayat al-Quran mengemukakan definisi, termasuk ketika menafsirkan ayat-ayat riba. Definisi riba yang dikemukakan oleh al-A lusi adalah:

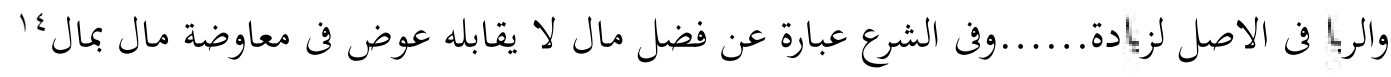

Penafsiran ayat-ayat riba ini menuju kepada pengertian riba nasi'ah. M enurut alThabathaba'i, definisi riba adalah menukar atau mengganti sesuatu dengan sesuatu yang sebanding dan ada tambahan. Dengan definsi ini kedua jenis riba, fadl dan nasi' ah masuk di dalamnya. Dalam uraian berikutnya ia menyebutkan bahwa riba ini terjadi ketika pihak pembeli atau peminjam dalam kesulitan. Kata "pembeli" menunjukkan indikasi riba fadl, dan kata "peminjam" menunjukkan indikasi riba nasi'ah.

Sedangkan Rasyid Ridla mengatakan bahwa yang dimaksud dengan riba di sini adalah riba yang dikenal di masa J ahiliyah, yang dipraktekkan oleh orang-orang $Y$ ahudi dan oleh orang-orang musyrik. ${ }^{15} \mathrm{H}$ anya saja, Rasyid Ridla dalam uraiannya lebih lanjut membatasi riba yang diharamkan oleh al-Quran yang memiliki sifat berlipat ganda. Menurut al-Shabuni, riba nasi'ah adalah riba Jahiliyah, di mana orang mengadakan peminjaman sejumlah harta untuk jangka waktu tertentu seperti setahun atau sebulan, dengan syarat ada tambahan karena panjangnya tenggang waktu. ${ }^{16}$

\footnotetext{
${ }^{11}$ al-K hazin, T afsir al-K hazin, J uz 1, (M esir: M usthafa al-B abi al-Halabi, 1955), 300

${ }^{12}$ M uhammad ibn U mar at-Tamimi al-Razi, T afsir al-K abir, J uz III (B eirut: Dar al-Fikr, 1981), 85

${ }^{13}$ Ibnu Taymiyyah, al-Radd 'ala al-M antikiyyin (Beirut: Dar al-M a' rifat, tt), 7

${ }^{14}$ Sayyid M ahmud al-A lusi, Ruh al-M a' ani, J uz III (B eirut: Dar Ihya' al-T urats al-A rabi, 1981), 48

${ }^{15}$ Rasyid Rida, Tafsir al-M anar, Juz III (M esir: al-Haiah al-M ishriyah al-'A mmah, 1990), 93

${ }^{16}$ Ali al-Shabuni, Rawai' al-Bayan; Tafsir A yat al-A hkam, Juz I (Damaskus: M aktabah al-Ghazali, 1980), 391
} 
Dari uraian para mufassir tentang riba, baik yang dituangkan dalam definisi maupun dalam bentuk gambaran praktis di masa Jahiliyah, riba yang mereka maksud dapat diidentifikasi sebagai berikut:

a) Terjadi karena transaksi pinjam meminjam atau utang piutang.

b) A da tambahan dari jumlah pinjaman ketika pelunasan.

c) Tambahan tersebut dijanjikan terlebih dahulu, setidaknya beberapa waktu sebelum pelunasan.

d) Tambahan itu diperhitungkan sesuai dengan panjang pendeknya tenggang waktu peminjaman.

Dalam mengungkap hakihat riba dalam al-Quran, Fakhr al-Razi menggali sebab dilarangnya riba dari pandangan ekonomi, yaitu sebagai berikut:

a) Riba memungkinkan seseorang memaksakan pemilikan harta dari orang lain tanpa ada imbalan. A pabila ditanya, mengapa orang tidak boleh memungut tambahan atas jumlah harta yang ada ditangan orang lain berdasarkan jangka waktu tertentu bukankah bila harta itu tetap berada di tangan pemiliknya kemudian dijadikan modal untuk dagang akan menghasilkan keuntunga? bukankah penyerahan harta terhadap orang lain berarti membuang kesempatan mendapatkan keuntungan yang diterima orang lain itu, sehingga pemilik harta berhak atas keuntungan karena telah membuang kesempatan itu? Fakhr al-Razi menjawab bahwa keuntungan yang akan diperoleh pihak peminjam masih "dalam perjudian", belum tentu datang, sedangkan pemungutan tambahan dari peminjam oleh pemberi pinjaman adalah hal yang pasti, tanpa resiko. Inilah yang dimaksud dengan "pemaksaan pemilikan harta" tersebut.

b) Riba menghalangi pemilik modal ikut serta berusaha mencari rezeki, karena ia dengan mudah membiayai hidupnya, cukup dengan bunga berjangka itu. Karena itu ia tidak mau lagi memangku pekerjaan yang berhubungan dengan dipakainya tenaganya atau sesuatau yang membutuhkan kerja keras. Hal ini akan membawa kemunduran masyarakat, sebagaimana dimaklumi bahwa dunia tidak bisa berkembang tanpa perdagangan, seni, dan olah tangan.

c) Bila diperbolehkan, masyarakat dengan maksud memenuhi kebutuhannya tidak segan-segan meminjam uang walaupun bunganya sangat tinggi. Hal ini akan merusak tata hidup tolong menolong, saling menghormati, sifat-sifat baik manusia dan persaan berhutang budi.

d) Dengan riba, biasanya pemodal semakin kaya, peminjam menjadi semakin miskin. Sekiranya riba dibenarkan, orang kaya akan menindas orang miskin dengan cara ini.

e) Larangan riba sudah ditetapkan oleh nash, di mana tidak harus seluruh rahasia tuntutannya diketahui manusia. Keharamannya itu pasti, walaupun orang tidak mengetahui persis segi pelarangannya. ${ }^{17}$

Penjelasan di atas, menunjukkan bahwa Fakhr al-Razi terlihat menggunakan pertimbangan rasional ketika menafsirkan ayat riba. Hanya pada poin terakhir, ia menggunakan pertimbangan ta'abbudi. Dari pertimbangannya itu diketahui bahwa riba

${ }^{17}$ M uhammad ibn U mar at-T amimi al-R azi, T afsir al-K abir, 87-88 
mempunyai unsur tidak adil, mendatangkan sikap malas dan kemunduran, menghilangkan sikap terpuji, dan membuat jarak antara si miskin dan si kaya. Dengan demikian, riba nasi'ah atau riba Jahiliyah sebagai riba yang dilarang dalam al-Quran menurut Fakhr al-Razi berdasarkan keempat unsur tersebut.

Y ang perlu diperhatikan adalah pada waktu itu formulasi riba yang dituangkan dalam definisi pinjam meminjam dengan kesepakatan ada tambahan ketika pelunasan relevan dengan unsur-unsur yang dikemukakan oleh Fakhr al-Razi. Jadi, keterangan tetang riba dengan formulasi itu sesuai dengan perkembangan zamannya.

Sifat riba yang menonjol bagi al-Thabathaba'i adalah pihak peminjam dalam keadaan sulit ketika akad riba dilakukan, dan tetap dalam keadaan sulit, baik ketika membayar tambahan maupun ketika pelunasan. Al-Thabathaba'i juga mengatakan bahwa riba menjurus kepada hancurnya masyarakat ekonomi lemah dan mengalirnya harta mereka ke tangan orang-orang kaya. ${ }^{18}$

M enghadapi bunga uang di bank, al-Thabathaba'i berpendapat bahwa bunga yang ditarik oleh bank dari nasabah sama dengan riba lain dalam dunia dagang. Keduanya sama-sama memberi beban yang semakin berat kepada masyarakat ekonomi lemah dalam kewajiban mereka membayar angsuran. Bahkan lebih dari itu, al-Thabathaba'i mengatakan bahwa kekacauan yang ditimbulkan oleh riba adalah licinnya jalan ke arah penumpukkan harta, penghentian uang dalam jumlah besar di bank-bank dari sirkulasi perdagangan, suburnya sikap malas bekerja karena kemewahan, dan menjamurnya pengangguran. ${ }^{19}$

Bagi al-Thabathaba'i, integrasi sosial itu terwujud dalam pertukaran harta benda untuk memenuhi kebutuhan hidup. Laba yang ditimbulkan oleh pertukaran dipandang sebagai ziyadah yang diimbali harga. Sedangkan riba dinilai sebagai ziyadah tanpa imbalan. ${ }^{20}$ Dari analisa al-Thabathaba'i diketahui bahwa gambaran tentang riba dalam al-Quran tidak sekedar yang dirumuskan dalam definisi. Tetapi, sifatnya yang menggelisahkan orang banyak harus diperhatikan.

Rasyid Ridla, seperti juga ulama lain menyatakan bahwa riba Jahiliyah telah menyiksa masyarakat, terutama masyarakat miskin. Ia melihat, kedhaliman yang terkandung dalam riba J ahiliyah adalah sifatnya yang berlipat ganda. K arenanya, lipat ganda yang disebut dalam Surah Ali 'Imran ayat 130 adalah merupakan hakikat riba Jahiliyah. Sebagaimana pandangan Muhammad Abduh yang mengatakan bahwa riba adalah istilah tentang penyerahan banyak dirham atau yang sejenis yang pengambilannya dengan lipat ganda pada kesempatan lain. Pengambilan ada imbalan materi maupun tenaga. Rasyid Ridla menambahkan, tambahan itu diberikan tidak didasarkan atas rasa suka rela, tetapi atas dasar keterpaksaan. ${ }^{21}$

Bagi Muhammad Abduh, bank merupakan lembaga keuangan yang fungsi menonjolnya adalah tempat penyimpanan uang atau harta orang kaya. Fungsi itu

\footnotetext{
${ }^{18}$ M uhammad Husain al-Thabathaba' i, al-M izan fi Tafsir al-Quran (B eirut: Dar al-K utub al-Islamiyah, tt), 430

$19 \mathrm{lbid}$.

${ }^{20}$ Ibid, 429

${ }^{21}$ Rasyid Rida, Tafsir al-M anar, 108
} 
dipandang menghambat sirkulasi dan kelancaran arus dagang. Bila uang yang seharusnya mempermudah kelancaran lalu lintas dagang itu menjadi tujuan usaha untuk disimpan, ini menjadi pertanda akan tercabutnya kemakmuran orang banyak, karena harta mereka akan terkuras di tangan orang-orang kaya yang pekerjaan mereka hanya menumpuk harta di tempat penyimpanan, seperti bank.

Walaupun A bduh tidak menyebut secara tegas bahwa bunga bank itu riba, tetapi dari ketidaksimpatiannya terhadap kegiatan bank yang dilihatnya, ia tidak menghalalkan bunga bank. Tetapi ketika ia dihadapkan kepada persoalan bunga tabungan pos, ia cenderung menghalalkannya. ${ }^{22}$ Artinya, meskipun tabungan pos dan bank-bank itu sama-sama mengeluarkan atau membayar bunga kepada penyimpan, tetapi ia hanya menghalalkan bunga di pos. Sikap A bduh yang tidak mentoleransi itu tampaknya dalam konteks orang miskin sebagai peminjam, bukan sebagai penyimpan, seperti yang terjadi dalam kegiatan tabungan pos, sehingga peluang adanya kedlaliman itu ada.

Menurut Abduh, orang yang menyerahkan harta kepada pihak lain untuk kepentingan usaha, kemudian ditentukan keuntungan tertentu untuk pemilik harta itu, maka tidak termasuk riba. Karena muamalah seperti itu mendatangkan manfaat dan keuntungan, baik bagi pemilik harta maupun bagi pengelolanya. Sedangkan riba hanya menguntungkan satu pihak dan merugikan pihak lain. Karena itu tidak mungkin hukum kedua hal ini sama menurut keadilan.

3. Riba menurut ulama' figh

M ayoritas ulama figh membagi riba menjadi dua, yaitu riba nasi' ah dan riba fadl. ${ }^{23}$ A yat al-Quran yang dijadikan sebagai dalil terlarangnya kedua macam riba itu adalah ayat-ayat yang terdapat dalam al-Baqarah dan Ali 'Imran. Tetapi dalam pengulasan ayat-ayat itu diterangkan bahwa ayat itu berbicara tentang riba nasi'ah, sesuai dengan kasus-kasus riba Jahiliyyah yang melatarbelakangi turunnya ayat tersebut.

B eberapa rumusan riba nasi'ah dalam madzhab-madzhab figh antara lain:

a) Madzhab Hanafi

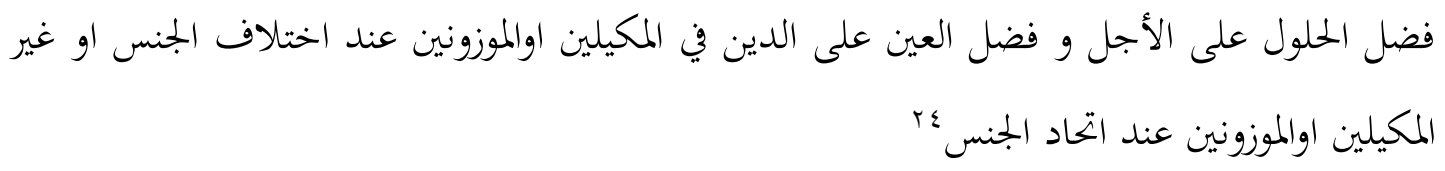

b) Madzhab Syafi'i

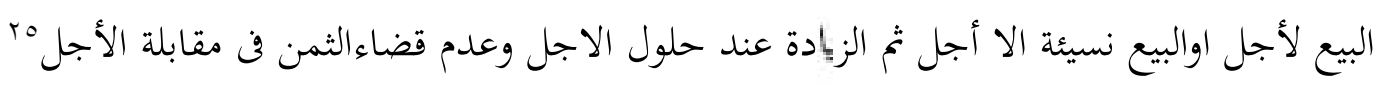

c) Kesimpulan Wahbah al-Zuhaily

\footnotetext{
${ }^{22}$ M uh. Zuhri, Riba..., 102

${ }^{23}$ M adzhab Syafi'i membagi riba menjadi tiga, yaitu riba fadl, riba nasi'ah dan riba yad. Di kalangan jumhur 'ulama' figh, riba yad ini termasuk riba nasi'ah. Perbedaan riba yad dan riba nasi'ah dalam madzhab Syafi'i adalah pada riba nasi'ah ketika terjadi akad, benda yang diakadkan sudah ada dan dapat diserahterimakan. Sedangkan pada riba yad, benda yang diakadkan belum ada ketika terjadi akad itu. Lihat Wahbah al-Zuhaily, al-Figh al-Islami wa A dillatuhu, Juz IV , (B eirut: Dar al-Fikr, 1985), 674

${ }^{24}$ Ibid., 672

25 Ibid., 674
} 


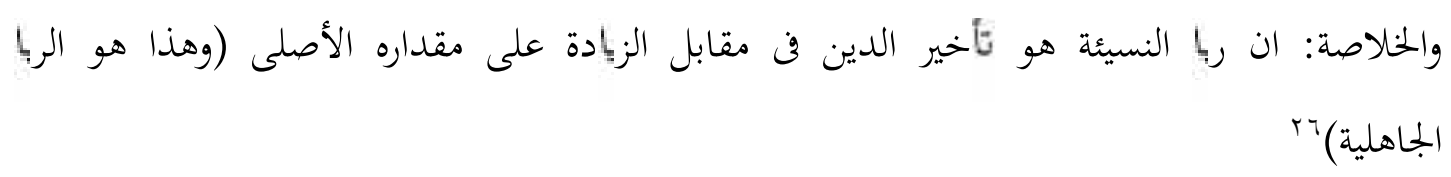

Dalam kurun waktu yang lama, tidak ada masalah yang muncul menyangkut pemahaman riba nasi'ah di kalangan para ulama'. K arena itu, perhatian mereka tertuju kepada benda-benda yang boleh dan tidak boleh diakadkan secara riba. Sebuah hadits yang diambil sebagai dasar para ulama' untuk menerangkan riba adalah :

$$
\begin{aligned}
& \text { عن عبادة قال سمعت رسول الله صلى الله عليه وسلم ينهى عن بيع الذهب بالذهب والفضة بالفضة والبر }
\end{aligned}
$$

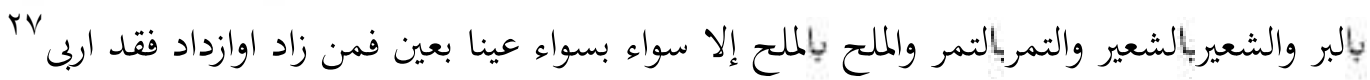

Menurut Ibnu Rusyd, hadits tersebut melarang pelebihan barang sejenis dalam tukar-menukar barang. Kemudian terdapat banyak hadits tentang larangan penundaan (riba nasi' ah), di antara hadits yang terkenal adalah hadits riwayat ' U mar bin K hattab :

$$
\begin{aligned}
& \text { سمع عمر بن الخطاب يخبر عن رسول الله صلى الله عليه وسلم قال الذهب بالذهب ربا إلا هاء وهاء والبر ، الذب } \\
& \text { بالبر ربا إلا هاء وهاء والتمر بالتمر ربا إلا هاء وهاء والشعير بالشعير ربا إلا هاء وهاء }
\end{aligned}
$$

Hadits pertama menyebut larangan jual-beli (tukar-menukar) barang sejenis di antara enam jenis barang (emas, perak, gandum, sya'ir, kurma, dan garam) kecuali sama banyaknya dan kontan. Dan lahiriyah hadits itu dapat diketahui bahwa terhadap keenam jenis barang yang disebut di dalamnya tidak boleh diadakan tukar tambah antara barang yang sejenis, baik kontan maupun berjangka. Dengan demikian, tidak boleh terjadi riba nasi' ah pada keenam jenis barang tersebut.

Setelah memperhatikan keenam jenis benda yang disebut dalam hadits itu, muncul beberapa pendapat ulama yang berbeda-beda. Ulama Hanafiyyah dan Hanabilah berpendapat bahwa emas dan perak merupakan simbol barang tambang yang ditakar. Sedangkan ulama Malikiyyah dan Syafi'iyyah berpendapat bahwa emas dan perak menjadi simbol uang, sedangkan keempat benda lainnya menjadi simbol makanan. ${ }^{29}$ Jadi, bagi golongan pertama, hutang benda sejenis yang dapat ditimbang dan ditakar tidak boleh ada kelebihan ketika pelunasan atau pengangsuran. Bagi golongan kedua, kelebihan tidak boleh terjadi pada hutang benda sejenis yang berupa uang atau makanan (termasuk bahan makanan). Selanjutnya keenam jenis benda tersebut dinamai bendabenda ribawi. A dapun benda lain seperti hewan tidak termasuk benda ribawi.

Rumusan riba nasi'ah yang dikemukakan oleh para ulama' figh tersebut apabila dibandingkan dengan rumusan ulama' tafsir tidak ada perbedaan. Dari rumusan itu dapat diketahui bahwa riba nasi'ah mempunyai unsur:

1) Terjadi karena peminjaman dalam jangka waktu tertentu.

\footnotetext{
${ }^{26}$ Ibid., 675

${ }^{27}$ Ibn Rusyd, Bidayah al-M ujtahid, (Indonesia: Dar al-Ihya' al-Kutub al-'A rabiyyah, tt), 96-97

${ }^{28}$ M uhammad ibn Ismail A bu A bdillah al-Bukhari, Shahih al-Bukhari, Juz 3 (Damaskus: Dar Thuq al-Najat, $1422 \mathrm{H}), 2134$

${ }^{29}$ W ahbah al-Zuhaily, al-Figh... , 676-686
} 
2) Pihak yang berhutang berkewajiban member tambahan kepada pihak pemberi hutang ketika mengangsur atau melunasi sesuai dengan perjanjian.

3) Objek peminjaman berupa benda ribawi.

Rumusan-rumusan riba nasi'ah itu telah dapat menggambarkan bentuk formal praktek riba jahiliyyah secara tepat. Kerugian sepihak dan kedhaliman sebagai hakekat riba pada waktu itu ditimbulkan oleh bentuk formal kegiatan ekonomi seperti yang tercantum dalam rumusan tersebut. K egiatan ekonomi yang formulanya seperti itu sejak dahulu sampai dengan masa fuqaha' tetap mendatangkan kedhaliman dan kerugian sepihak. Tegasnya, setiap tambahan atas jumlah pinjaman itu dapat dipastikan mendatangkan kedhaliman sebagaimana yang telah dijelaskan di dalam al-Quran Surat al-B aqarah ayat 279. K arena begitu melekatnya asosiasi antara "tambahan atas jumlah pinjaman" dengan "penyengsaraan" itu, maka "penyengsaraan" tidak perlu disebut lagi dalam rumusan, baik oleh ulama' fiqh maupun ulama' tafsir.

Di zaman modern, peranan uang sebagai standar harga dan sarana pertukaran barang semakin kuat. Dengan begitu orang tidak lagi jual-beli kurma dengan gandum, garam dengan garam, atau garam dengan gandum, tetapi semuanya ditukar dengan uang. Transaksi penyimpanan maupun peminjaman dalam kegiatan ekonomi juga tidak dengan barang, tetapi dengan uang. ${ }^{30}$ Disamping itu, bentuk-bentuk kegiatan ekonomi semakin banyak ragamnya. Pergeseran nilai mulai terlihat. A pa yang dulu dianggap telah baku, kini dipertanyakan. Kalau dulu setiap "tambahan atas pinjaman" dipastikan akan mendatangkan "kesengsaraan", kini dipertanyakan. Bunga uang di berbagai lembaga keuangan sebagai konsekuensi utang piutang, di satu pihak terperangkap dalam formula riba, tetapi di sisi lain mendatangkan keuntungan menjadi masalah serius dalam kajian hukum Islam.

4. Pandangan ulama Indonesia

a) Nahdhatul Ulama

1) Sebagian ulama mengatakan bunga sama dengan riba, sebagian Iain mengatakan tidak sama dan sebagian lain mengatakan syubhat.

2) Rekomendasi: agar PBNU mendirikan bank Islam NU dengan sistem tanpa bunga (B ahtsul M asail, M unas B andar Lampung, 1992)

b) Muhammadiyah

1) Bunga yang diberikan oleh bank-bank milik nagara kepada nasabahnya atau sebaliknya yang selama ini berlaku termasuk mutasyabihat.

2) Menyarankan kepada PP Muhammadiyah untuk mengusahakan terwujudnya konsepsi sistem perekonomian khususnya lembaga perbankan yang sesuai dengan kaidah Islam (Lajnah Tarjih Sidoarjo, 1968)

\section{Riba dalam B unga B ank (B unga Koperasi) dalam Pinjaman dan B unga B ank J ual B eli}

Sebagai bahan dalam memperdalam pembahasan riba, coba kita perhatikan firman

\footnotetext{
${ }^{30} \mathrm{U}$ ang mempunyai fungsi sebagai alat tukar, satuan hitung, penimbunan kekayaan, dan standar pencicilan hutang. L ihat M uchdarsyah Sinungan, U ang dan B ank (Jakarta: Bina A ksara, 1989), 6-9
} 
Allah berikut ini:

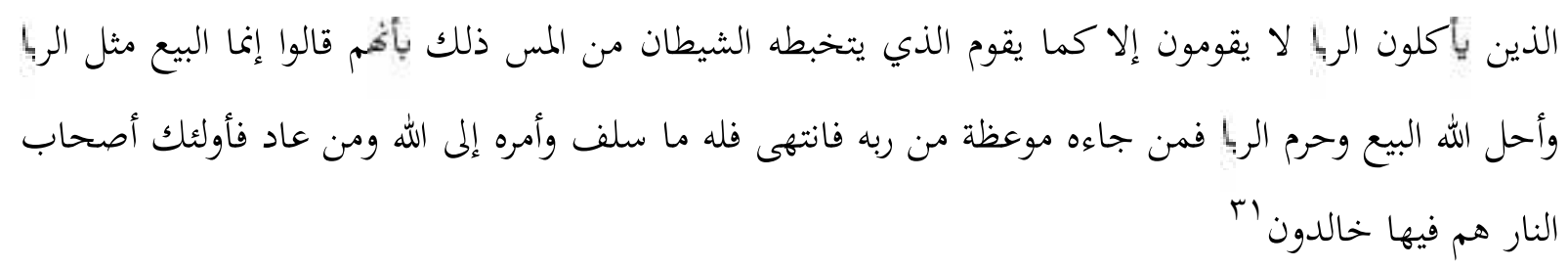

Sebelum kita membahas lebih jauh tentang riba, yang harus kita perhatikan adalah riba itu bisa terjadi dalam transasksi hutang, jual beli dan juga bisa terjadi dalam transaski investasi.

Dalam perspektif hutang, menurut B adr ad-Din al-A yni, definisi riba adalah:

$$
\text { الأصل في الربا وهو في الشرع الزيادة على أصل المال من غير عقد تبايع بان }
$$

Sementara Raghib al-A sfahani menjelaskan bahwa riba adalah penambahan atas harta pokok. ${ }^{33}$ Sedangkan Imam Nawawi memberikan definisi riba dengan penambahan atas harta pokok karena unsur waktu. ${ }^{34}$

Bunga bank dalam transaksi jual beli, semisal kredit perumahan, kendaraan bermotor, dan yang semisal dengan itu, sebetulnya mekanismenya berbeda dengan bunga bank dalam pinjaman. Untuk itu, analisis terhadap bunga bank dalam jual beli kurang tepat jika disamakan dengan bunga bank dalam pinjaman. Bunga bank dalam jual beli sebetulnya merupakan profit margin sehingga jika kita membandingkan bunga bank dalam jual beli ini dengan profit margin dalam transaksi murabahah akan nampak seolah tidak ada beda. Namun ketika kita amati lagi, besaran bunga kredit tersebut bergerak mengikuti suku bunga bank Indonesia. A rtinya, jika suku bunga naik maka bunga kredit tersebut juga naik dan sebaliknya. Dalam hal ini, terjadi perubahan harga untuk satu barang di tengah masa angsuran kredit. Hal ini masuk dalam kategori satu barang dua harga, atau bahkan harga yang terus berubah. Sementara dalam murabahah, besaran profit margin harus fixed dari awal transaksi hingga selesai.

B unga bank dalam investasi juga termasuk riba karena sama persis dengan bunga bank dan bunga koperasi dalam pinjaman konsumtif dan keuntungannya tidak didasarkan kepada nisbah dari hasil usaha, namun hanya berdasar jumlah uang yang dikeluarkan.

J adi bunga bank dalam investasi dengan profit sharing dan revenue sharing, merupakan dua konstruksi bangunan yang berbeda secara diametral dan fundamental. Hal inilah yang menjadikan fenomena krisis moneter tahun 1997-1998 menjadi momentum pernyataan bahwa bank syariah lebih tahan terhadap krisis jika dibandingkan dengan bank konvensional.

\section{B ahaya Riba}

A dapun bahaya atau alasan mengapa riba dilarang di dalam Islam antara lain:

\footnotetext{
${ }^{31}$ Q.S. al-B aqarah: 275

${ }^{32}$ Badr ad Din al-A yni, Umdatul Qari, vol. V (Constantinople: M athba' ah al-A mira, 1310 H), hlm. 436

${ }^{33}$ Raghib al A sfahani, dikutip oleh M uhammad Syafi'i A ntonio, Bank Syariah dari teori ke praktek (J akarta: Gema Insani Press, 2001), hlm 38

${ }^{34} \mathrm{~A}$ bdurrahman al-J aziry, al-Fiqh ‘ala M adzahib al-A rba' ah (B eirut: Darul Q alam, tt)
} 
1. Hati mudah keruh (aghyar) meskipun andaikan lidahnya basah oleh dzikir dan mudah terjangkit penyakit abnormal, idiot dan lain-lain.

2. Tidak akan mendapatkan keberuntungan, utamanya di akhirat.

3. Tidak dapat berdiri melainkan seperti berdirinya orang yang kemasukan syaitan lantaran (tekanan) penyakit gila.

4. Satu dirham yang diambil dari riba itu dosanya lebih besar di sisi Allah dari pada (dosa) 36 kali zina yang dilakukan oleh seseorang. Dan dosa dari riba yang paling rendah menurut riwayat yang lain adalah seperti dosanya seseorang yang menyetubuhi ibunya.

5. Allah melaknat orang yang memakan riba, yang mewakili transaksi riba, dua orang saksinya dan orang yang menuliskannya.

6. Orang yang telah mengetahui bahwa yang dilakukannya itu termasuk riba tetapi masih terus diulangi (mengambil riba), maka orang itu adalah penghuni-penghuni neraka dan kekal di dalamnya.

7. Doanya terhijab atau tidak dikabulkan dan mereka tidak diampuni oleh Allah hingga mereka benar-benar bertaubat dan meninggalkan perbuatan tersebut.

\section{Kesimpulan}

Dari definisi riba dan bunga dalam pinjaman ke bank di atas, dapat ditarik hubungan bahwa mekanisme bunga bank dan bunga koperasi dalam pinjaman sama dan identik dengan pengertian riba. A pabila bunga bank adalah riba, maka hukum bunga pinjaman ke bank sama dan linier dengan hukum riba, yakni haram.

J enis-jenis riba yang terjadi dan dilakukan dalam kehidupan sehari-hari, antara lain riba qardl (kelebihan atas pinjaman dalam hutang), riba J ahiliyah (memberikan denda karena telat membayar hutang/pinjaman), riba fadhl (kelebihan barter barang ribawi) dan riba nasi'ah (tambahan penangguhan pembayaran).

A dapun bahaya terutama dari mereka yang memakan riba adalah tidak diampuni oleh A llah hingga mereka benar-benar bertaubat dan meninggalkan perbuatan tersebut sehingga Allah mengancam akan melaknat orang yang memakan riba, yang mewakili transaksi riba, dua orang saksinya dan orang yang menuliskannya.

Empat orang yang menjadi hak bagi Allah untuk tidak memasukkan mereka ke dalam surga dan tidak merasakan mereka pada kenikmatannya, yaitu peminum arak, pemakan riba, pemakan harta anak yatim, dan orang yang menyakiti kedua orang tuanya.

\section{D aftar Pustaka}

A hmad, A bi husain ibn Faris ibn Zakariah, M aqayis al-Lughah, B eirut: Dar Ihya' al-Turats al-A rabiy, 2001

al-A lusi, Sayyid M ahmud, Ruh al-M a' ani, B eirut: Dar Ihya' al-T urats al-A rabi, 1981 al-A yni, B adr ad Din, U mdatul Q ari, Constantinople: M athba' ah al-A mira, $1310 \mathrm{H}$ al-Bukhari, Muhammad ibn Ismail Abu Abdillah, Shahih al-Bukhari, Damaskus: Dar Thuq al-Najat, $1422 \mathrm{H}$ 
al-Faruqi, Ismail Raji, "Is the M uslim Definable in Term of His Economic Pursuits?", dalam Islamic Perspectives, ed. Khursyid A hmad M dan Zafar Ishaq Anshari, London: The Islamic Foundation, tt

al-J aziry, A bdurrahman, al-Figh ala M adzahib al-A rba' ah, B eirut: Darul Qalam, tt al-K hazin, Tafsir al-K hazin, M esir: M usthafa al-B abi al-Halabi, 1955

al-Razi, M uhammad ibn U mar at-Tamimi, T afsir al-K abir, J uz III, B eirut: Dar al-Fikr, 1981 al-Shabuni, Ali, Rawai' al-Bayan; Tafsir A yat al-A hkam, Juz I, Damaskus: Maktabah alGhazali, 1980

al-T habathaba'i, M uhammad Husain, al-M izan fi Tafsir al-Quran, B eirut: Dar al-Kutub alIslamiyah, tt

al-Zuhaily, Wahbah, al-Figh al-Islami wa A dillatuhu, B eirut: Dar al-Fikr, 1985

A ntonio, M. Syafi'i, B ank Syari' ah dari Teori ke Praktik, Jakarta: Gema Insani, 2001

Chapra, M. U mer, Islam dan T antangan Ekonomi, terj. Ikhwan A bidin, J akarta : Gema Insani Press, 2000

el Diwany, Tarek, Bunga Bank dan Masalahnya Suatu Tinjauan Syar'i dan Ekonomi Keuangan, Jakarta: A K B A R M edia Eka Sarana, 2003

Ibn 'A rabi, A hkam al-Qur' an, Q ahirah: Dar Ihya' al-Kutub al-'A rabiyah, 1957

Ibn Kasir, T afsir al-Qur' an al-'A zim, Q ahirah: Dar Ihya' al-Kutub al-'A rabiyah, 1952

Ibnu Taymiyah, al-Radd 'ala al-M antiqiyyin, B eirut: Dar al-M a' rifat, tt I bn Rusyd, Bidayah al-M ujtahid, Indonesia: Dar al Ihya' al-kutub al-'A rabiyyah, tt K hallaf, A bdul Wahab, 'Ilm U shul Figh, Kairo: Dar al-K uwaitiyah, 1968 Karim, A diwarman A ., Sejarah Pemikiran Ekonomi Islam, Raja Grafindo Persada, 2006 Qutb, Sayyid, Fi Zilal al-Qur' an, juz XXI, Beirut: Dar al-Turas al-'A rabi, 1967 Ridla, Rasyid, Tafsir al-M anar, M esir: al-Haiah al-M ishriyah al-'A mmah, 1990 Sinungan, M uchdarsyah, U ang dan Bank, Jakarta: Bina A ksara, 1989

Zuhri, M uh., Riba dalam al-Quran dan Masalah Perbankan; Sebuah Tilikan Antisipatif, J akarta: PT. Raja Grafindo Persada, 1997 